\title{
Evolution of patients with heart disease after cardiopulmonary rehabilitation program: case report
}

\author{
Evolução de paciente cardiopata após protocolo de \\ reabilitação cardiopulmonar: relato de caso
}

\author{
Saulo Fabrin ${ }^{[a, b]}$, Nayara Soares ${ }^{[a, b]}$, Simone Cecílio Hallak Regalo ${ }^{[b]}$, \\ Jacqueline Rodrigues de Freitas Vianna $^{[\mathrm{a}]}$, Eloisa Maria Gatti Regueiro ${ }^{[\mathrm{a}, \mathrm{c}]^{*}}$ \\ [a] Centro Universitário Claretiano, Batatais, SP, Brazil \\ [b] Universidade de São Paulo (USP), São Paulo, SP, Brazil \\ [c] Centro Universitário Unifafibe (UNIFAFIBE), Bebedouro, SP, Brazil
}

\begin{abstract}
Introduction: Recovery and maintenance of patients suffering from heart and respiratory diseases using the cardiopulmonary rehabilitation program (CPRP) help maintain their functionality and improve the activities of daily living (ADLs) carried out according to their functional limitations. Objective: To investigate the efficacy of a CPRP in a patient with cardiopulmonary disease, following a 5-month training program. Methods: A 66-year-old female patient, body weight $78 \mathrm{~kg}$, height $1.55 \mathrm{~m}$, diagnosed with acute myocardial infarction and bronchial asthma underwent a six-minute walk test (6MWT) to measure exercise tolerance; the Wells Bench was used to measure the flexibility of the posterior chain and lower limbs (LL), and a handheld dynamometer (HHD) was used to measure upper limb strength (ULS).Vital sign measurements include blood pressure (BP), heart rate (HR), respiratory rate (RR), oxygen saturation (SpO2) as well as dyspnea and LL fatigue (modified Borg scale) at rest, during and after 5-month CPRP. Results: An increase of 145 meters during the cardiopulmonary rehabilitation program i.e. 30\% of walk distance (WD) in the 6MWT (pre $=345$, post $=490 \mathrm{~m})$. There was an increase of $32 \%$ in flexibility (pre $=13$, post $=19 \mathrm{~cm})$; in right upper limb (pre $=26$, post $=60 \mathrm{kgf}$ ) and left lower limb strength (pre $=28$, post $=72 \mathrm{kgf}$ ), there was an increase of $57 \%$ and $61 \%$, respectively. Conclusion: The CPRP proved to be effective in increasing exercise capacity, upper limb strength and flexibility of the posterior chain and lower limbs.
\end{abstract}

Keywords: Myocardial Infarction. Bronchial Asthma. Rehabilitation. Physiotherapy.

\footnotetext{
* SF: BS, e-mail: saulo.fabrin@gmail.com NS: BS, e-mail: naya_lmn@hotmail.com SCHR: PhD, e-mail: simone@forp.usp.br JRFV: PhD, e-mail: jacrfvianna@uol.com.br EMGR: PhD, e-mail: eloregueiro@yahoo.com.br
} 


\section{Resumo}

Introdução: A recuperação e manutenção de pacientes que sofrem de problemas cardíacos e respiratórios utilizando o Protocolo de Reabilitação Cardiopulmonar (PRCP) auxiliam na funcionalidade e no desenvolvimento das atividades de vida diárias (AVD) respeitando os limites fisiológicos. Objetivo: Verificar a eficácia de um PRCP em uma paciente com doença cardiorrespiratória, após cinco meses de treinamento. Métodos: Foi avaliado um paciente, gênero feminino, 66 anos, peso $78 \mathrm{Kg}$, altura 1,55 m, apresentando infarto agudo do miocárdio (IAM) e asma brônquica, submetido a avaliação da tolerância ao exercício pelo Teste de Caminhada de Seis Minutos (TC6), da flexibilidade da cadeia posterior e de membros inferiores (MMII) pelo Banco de Wells e avaliação da força de membros superiores (MMSS) pela dinamometria, com mensuração dos sinais vitais: pressão arterial (PA), frequência cardíaca $(F C)$, frequência respiratória (FR), saturação periférica de oxigênio (SpO2), bem como dispnéia e cansaço de MMII avaliados pela Escala de Borg (EB-CR10), em repouso, durante e após a realização dos testes, pré e pós cinco meses do PRCP. Resultados: Verificou-se aumento de 145 metros no período do PRCP, ou seja, 30\% da distância percorrida (DP) no TC6 (pré=345, pós=490 metros), na flexibilidade (pré=13, pós=19cm) observou-se um aumento de 32\% e na força de MMSS observou-se para MSD (pré=26, pós=60 Kgf) e MSE (pré=28, pós=72 Kgf) um aumento de 57\% e 61\% respectivamente. Conclusão: Conclui-se que o PRCP no caso relatado mostrou-se eficaz no aumento da capacidade de exercício, força de MMSS e flexibilidade da cadeia posterior e de MMII.

Palavras-Chave: Infarto do Miocárdio. Asma Brônquica. Reabilitação. Fisioterapia.

\section{Introduction}

Cardiovascular diseases represent $30 \%$ of all deaths in the Brazilian population. However, preventive measures to reduce the risk factors can minimize the impact of these diseases (1,2). Aging is one of the risk factors that not only contributes to the decline in functional capacity but also to increase the death rate, particularly when associated with comorbities $(3,4)$.

Physical activity is one of the ways of preventing the emergence of such risks; however, its implementation must be prescribed and monitored, even when performed in groups, which is an alternative for health promotion to a larger number of people. In addition, it is necessary to look for practical and low cost alternatives for the evaluation and follow-up of patients with risk factors that enrolled in community-based physical activity programs (5).

Among the low-cost measurement tools to evaluate the risk factors, exercise tolerance, cardiorespiratory changes and the capacity of the individual to perform ADLs is the six-minute walk test (6MWT). It is a relatively simple and easy to perform measure of aerobic exercise capacity and is highly reproducible. The test is carried out at a submaximal level of exercise (6).

Flexibility is universally recognized as one of the most important components of physical fitness. Some flexibility tests are part of the main battery of physical fitness assessment, associated with either the performance or health. Age and gender can be factors that limit flexibility (7). Physiotherapy is one of the medical and rehabilitation specialties that addresses the training of these physical skills and offers different physiotherapeutic techniques, especially kinesiotherapy. Flexibility of the posterior chain can be measured using the Wells bench test, which is also a simple and low cost tool (8).

Muscle weakness, combined with balance impairment, and reduced reaction time are partly responsible for the increase in the number of falls among the elderly $(9,10)$, either healthy or suffering from any cardiopulmonary disease. Physical activity is one of the important intervention strategies for the prevention of unintentional falls, maintenance of muscle strength and bone mineral density (11). A dynamometer is a common method to measure the grip strength of the upper limbs (12).

The recovery and maintenance of patients suffering from cardiac and respiratory diseases using the cardiopulmonary rehabilitation program (CPRP) help maintain their functionality and improve the activities of daily living (ADLs), respecting their physiological limits, and giving priority to three aspects: aerobic, strength and flexibility training. Therefore, the main purpose of this study was to investigate the efficacy of a CPRP in a patient with bronchial asthma and history of acute myocardial infarction. 


\section{Methods}

Subject

A 66-year-old female patient, body weight $78 \mathrm{~kg}$, height $1.55 \mathrm{~m}$, diagnosed with acute myocardial infarction and bronchial asthma. According to the physiotherapeutic diagnosis, the patient had low cardiorespiratory fitness, low aerobic capacity, dyspnea and peripheral muscle weakness.

The study was approved by the Research Ethics Committee of the Claretiano Centro Universitário (case N. 67/2011). The participant was informed about the experiment and agreed to participate by providing her free and informed consent according to resolution $466 / 12$ of the Health National Council.

\section{Experimental procedure}

- Six-minute walk test

The 6MWT was performed on a $30 \mathrm{~m}$ long corridor, following guidelines by the American Thoracic Society (ATS) (13). The following vital signs were previously collected: heart rate (HR), respiratory rate (RR), blood pressure (BP), peripheral oxygen saturation (Sp02), as well as dyspnea and lower limb (LL) fatigue using the Borg CR-10 (BS-CR10). Following the test guidelines, the patient wore light clothes, appropriate footwear and fulfilled all recommendations.

Every minute, HR and SpO2 were collected using a Digit ${ }^{\circledast}$ Finger Oximeter (Smiths Medical); fatigue and dyspnea, using the BS-CR10. The therapist stood behind the patient not to influence the patient's rhythm, using words of encouragement, "You are doing fine", "Keep the pace". After completing the test, all measurements were collected again, including the walk distance (WD). After a ten-minute rest, $\mathrm{HR}, \mathrm{RR}, \mathrm{SpO} 2$, fatigue and dyspnea were measured to verify the patient's recovery, following the exercise. The test was repeated after half an hour (13).

- Wells Bench

The measurements of the trunk and LL flexibility were performed using the Wells bench. The bench was $35 \mathrm{~cm}$ high and wide, and $40 \mathrm{~cm}$ long. The top of the box has an indicator marked $15 \mathrm{~cm}$, and another indicator placed horizontally to allow the hands to move as forward as possible. The patient sat on a mat, with the soles of both feet maintaining contact with the box.
Three trials were performed and the values presented were: up to $11 \mathrm{~cm}=$ very poor; 12 to $13 \mathrm{~cm}=$ poor; 14 to $18 \mathrm{~cm}=$ average; 19 to $21 \mathrm{~cm}=$ good; $\pm 22 \mathrm{~cm}=$ excellent (14).

\section{- Dynamometry}

The grasping strength of the hand was measured using a hand-handle dynamometer (HHD). The subject was sitting comfortably, with the shoulders adducted, the elbow flexed at $90^{\circ}$, forearm and wrist in neutral position. Three measurements were taken from each limb. The results were collected and the dynamometer pointer was reset to zero before each measurement $(15,16)$.

The CPRP included appropriate physical activities divided into three measurable parts: endurance, strength and flexibility, as shown in the organizational chart that contains the following parts:

1) Vital Signs Data Collection-BP, RR, HR and SpO2 were measured. The Borg rating scale was used to evaluate dyspnea and levels of fatigue of $\mathrm{LL}$, ranging from 0 (nothing at all) to 10 (very, very severe).

2) Warm-up-it started with a 1-minute slow walk; shortly after, the speed was increased, with a faster walk pace for one more minute; the patient then walked kicking her heel toward her buttocks alternately for one more minute. Next, the patient walked a zigzag course with obstacles (cones) for two minutes. One aerobic step was placed at the beginning and another at the end of the course. Following the walk course, the patient stood up moving her shoulders up and down, flexing her hip with the knees flexed, with knees extended, making circular movements with the hands over the shoulders (five forward and five backwards) and half-kneeling, one minute for each exercise, totaling 10 minutes.

3) Aerobic training - A stationary bike was used for warm-up with speeds ranging from 25 and 30 RPM for 3 minutes. The speed was then increased from 40 and 60 RPM for 27 minutes. The speed was slowed for 3 minutes and then was back to 25 to 30 RPM until the total time of 30 minutes. The vital signs during training were collected every five minutes.

4) Resistance training (RT) - The loads used in RT were estimated by the one repetition maximum test (1RM also called one execution maximum), 
which is operationally defined as the heaviest load that can be moved over a specific range of motion (17). Vital data were collected every 5 minutes. RT was performed on alternate days; upper limb strength (ULs) on Tuesday and lower limb strength (LLs) on Thursday, with 3 series of 10 repetitions for each exercise. The exercise protocol included the following body parts and muscles: Biceps: Patient sat and held a dumbbell while flexing and extending the elbow. Triceps: Patient sat with the trunk semi-flexed (semifowler position) while extending the elbow and holding the dumbbell with both hands, moving it towards the frontal bone of the face. The physical therapist helped stabilize the elbow in the desired position. Deltoid: Patient stood in front of the mirror and performed the movements of abduction and adduction of shoulder with the dumbbell. Grand dorsal and rhomboid: Patient sat on a rowing machine and performed (back and forth) a retraction movement of the scapula, adduction of the shoulder and flexion of the elbow. Chest: Patient sat on the chest machine and performed abduction and adduction in horizontal plane (of the scapula). Quadriceps: Patient sat on a table and extended both knees. Hamstrings: Patient sat on a table and bent both knees. Gastrocnemius: Patient sat with the instrument on the knee and performed plantar flexion. Abductors: Patient sat on the abductor and performed hip abduction. Adductors: Patient sat on the adductor and performed hip adduction.

5) Stretching - Following the resistance training, stretching was performed for 20 seconds for each exercise: Cervical stretching: the patient stood and tilted the head towards one of the shoulders and held; repeated the movement with the contralateral shoulder. The patient clasped both hands and pushed the chin up and held; then with both hands on the occipital bone pushed the neck down. Stretching the ULs: Fist and finger extensors: patient with the elbow extended pulled the wrist with the other hand until a slight discomfort was felt, maintaining the wrist extension. Wrist and finger flexors: patient in the same position flexed the wrist, using the other hand and kept stretching the fist down until a slight discomfort was felt. Triceps: with one hand, the patient tried to reach the scapula using the other hand. Stretching of the thoracic and lumbar spine: with both hands clasped, the subject turned them over so that the palm faced up, extending the elbow as much as possible. Holding onto the stall bars, feet slightly apart, leaned backwards until the spine was stretched. Stretching the LLs: Hamstrings, gastrocnemius and soleus: holding onto the stall bars, feet next to the bars, the subject stretched the spine, throwing all the weight backwards until the lower chain of muscles was stretched. Quadriceps and Iliopsoas: holding onto the stall bars, lifted the right foot up off the floor with one hand to stretch the quads and iliopsoas. Gastrocnemius and soleus: with the tip of the feet on a surface, the subject bent the body forward until the calf was stretched.

6) Completion - Collection of vital signs and release of patient.

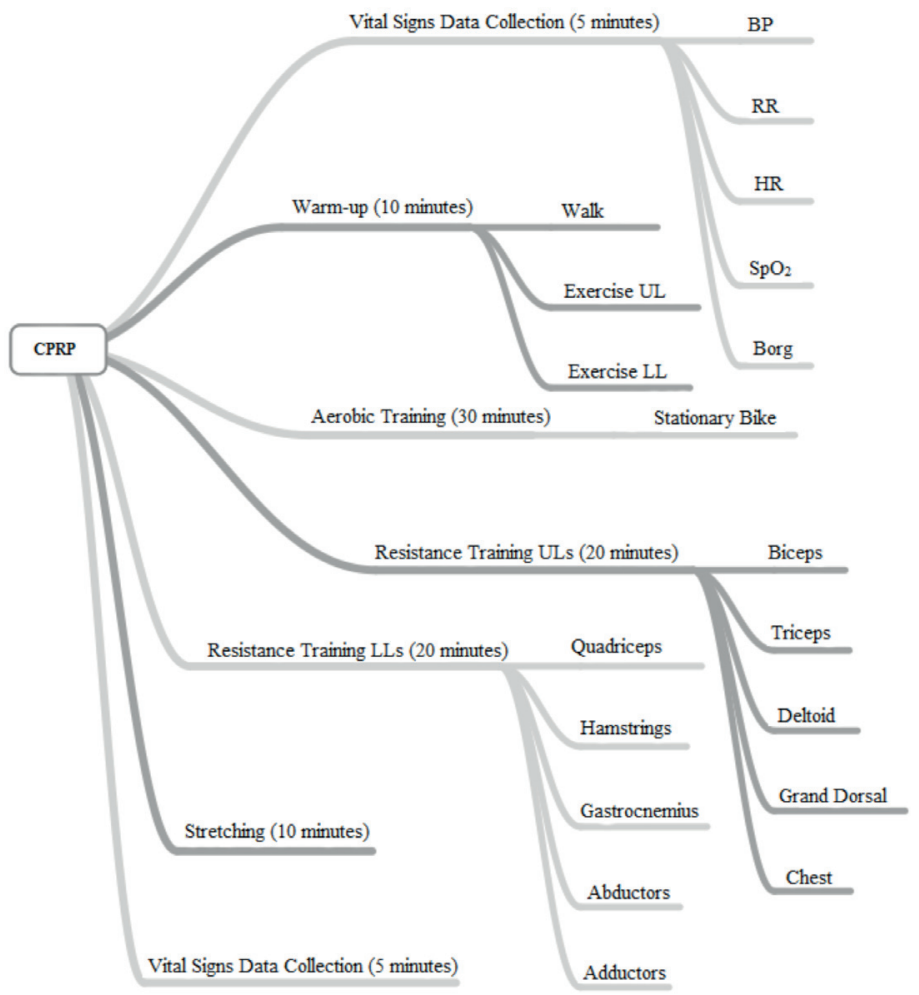

Figure 1 - Organizational chart of the Cardiopulmonary Rehabilitation Program.

After completing all the necessary tests, the CPRP started with a twice weekly schedule, 90 minutes each session, for a period of five months. At the end of rehabilitation program, the patient was evaluated again with the same measurement tools: 6WT, Wells Bench and Dynamometry. 


\section{Results}

The patient has obtained an increase of $145 \mathrm{~m}$ in walk distance in the 6MWT (Figure 2), following the 5 -month CPRP, which is equivalent to $30 \%$ of the WD in the 6 MWT pre rehabilitation (pre $=345 \mathrm{~m}$, post $=490 \mathrm{~m}$ ).

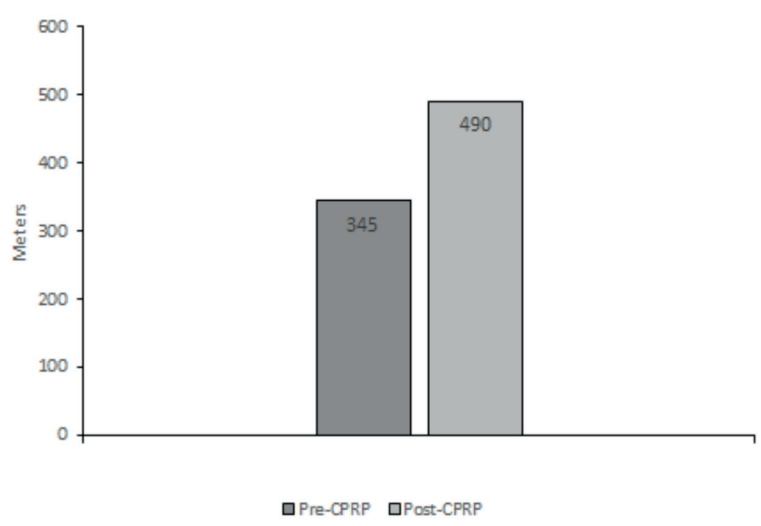

Figure 2 - Walk distance in the 6MWT pre and post CPRP.

For flexibility, an increase of $32 \%$ (pre $=13 \mathrm{~cm}$, post $=19 \mathrm{~cm}$ ) was observed, as illustrated in Figure 3 .

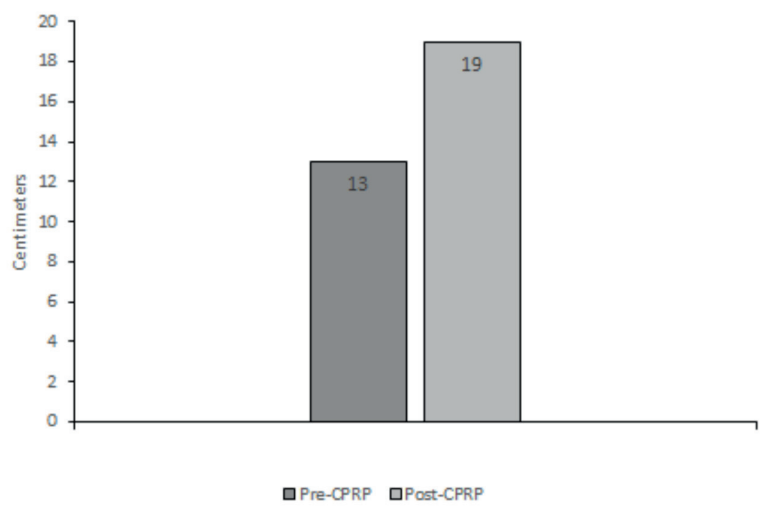

Figure 3 - Comparison of flexibility $(\mathrm{cm})$ pre and post CPRP.

For muscle strength, the right upper limb (RUL) showed an increase of $57 \%$ (pre $=26 \mathrm{kgf}$, post $=60 \mathrm{kgf}$ ) post rehabilitation; the left upper limb (LUL) showed an increase of $61 \%$ (pre = 28kgf, post = $72 \mathrm{kgf}$, indicating a minimum gain of $30 \%$ (Figure 4 ).

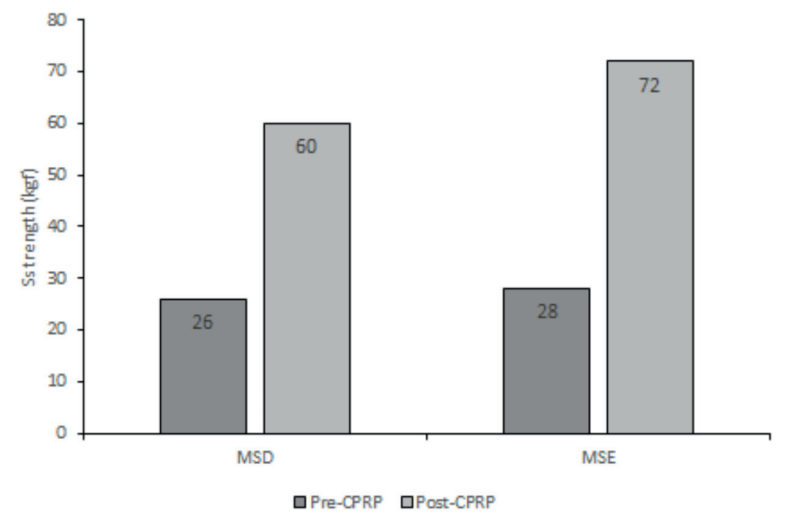

Figure 4 - Comparison of strength (kgf) pre and post CPRP.

The vital sign values remained stable and some presented a gradual improvement, following the five month rehabilitation program (Table1).

Table 1 - Comparison of vital sign values pre and postCPRP

\begin{tabular}{ccc}
\hline Vital Signs & Pre-CPRP & Post-CPRP \\
\hline Heart Rate $(\mathrm{bpm})$ & 78 & 88 \\
Arterial Pressure $(\mathrm{mmHg})$ & $140 \times 80$ & $160 \times 80$ \\
Respiratory Rate $(\mathrm{rpm})$ & 20 & 20 \\
Sp02 $(\%)$ & 98 & 96 \\
Borg Dyspnea & 3 & 1 \\
Borg LLs & 3 & 1 \\
\hline
\end{tabular}

\section{Discussion}

The efficiency of the CPRP can be verified through well defined variables using tests to assess the WD in the 6MWT, flexibility and peripheral muscle strength in ULs. Using a group of patients with chronic heart failure, Bittner et al. (17) observed that those who walked less than 350 meters had a higher risk of death when compared to those with a walking course of more than 450 meters. With those results, it was observed that a distance of $350 \mathrm{~m}$ in the 6MWT would include the case reported here in the group at greatest risk of death, which corroborates other authors who have also showed a distance of $350 \mathrm{~m}$ as cut-off point for patients with chronic obstructive pulmonary disease, chronic heart failure and pulmonary arterial hypertension $(18,19)$. 
After the CPRP, an increase to $490 \mathrm{~m}$ revealed a better prognosis, with a lower risk of death. Opasich et al. (20) studied patients undergoing cardiac surgery and found that the distance walked in the 6MWT and a left ventricular ejection fraction (EF) greater than $50 \%$ in patients aged 61 to 70 years was on the averaged 330 \pm 98 meters for men and $255 \pm 93$ meters for women. In another study, the receiver operating characteristic (ROC) curve was used for statistical analysis (21). It was observed that the best cut-off point for the WD in the 6MWT was 520 meters in 58-year-old patients and an $\mathrm{EF}$ of $35 \%$. This means that for a patient with a WD < 520 meters, or the age $\geq 58$ years, and ejection fraction lower than $35 \%$, the probability of death was higher.

The 6WDT is a simple, easily applied and inexpensive method to objectively assess the level of functional capacity, according to ATS (22). In our study, this test was well tolerated by the patient, without the need for pauses or interruptions due to symptoms and/or discomforts. Therefore, it was possible to assess the functional capacity impairment and to confirm the improvement in exercise capacity by increasing the walk distance after CPRP. These results obtained were similar to those found by Kervio et al. (23) in healthy elderly who performed the 6MWT and did not have to interrupt the test. While assessing elderly patients using the 6 WDT, Enright et al. (24) recommended its use to assess the impact of the multiple comorbidities, including cardiovascular diseases. The same recommendation was given by Bautmans et al. (25) that administered the 6MWT to elderly persons that were subdivided in healthy patients and in patients with risk factors of cardiovascular diseases and observed longer WD in healthy subjects, when compared to those who had risk factors for diabetes mellitus and systemic arterial hypertension (SAH). Baptista et al. (26) also obtained an interesting finding in a study with patients submitted to myocardial revascularization. The group that walked $<350$ m displayed increased WD two months following surgery, with improved functional capacity (233 \pm $106 \mathrm{~m}$ vs. $348 \pm 87 \mathrm{~m}, \mathrm{p}<0.01$ ). For flexibility, according to Shephard (27), over the span of working life, adults lose some 8-10 cm of lower-back and hip flexibility, as measured by the "sit-and - reach" test. Many contributing factors include tendon, ligament and joint capsule stiffness due to collagen deficiency. The restriction in the range of movement at the major joints becomes yet more pronounced during retirement, and eventually, independence is threatened because the subject cannot get into a car or use the restroom, ascend a small step, or complete the movements required for dressing and combing the hair. Flexibility can be conserved by taking the main joints through their full range of motion daily. This was considered a relevant factor in our study, which proved the effectiveness of the stretching exercises used and observed while performing the Wells Bench test.

In another controlled study with women aged 55 to 77 years, Hoerger and Hopkins (28) found improvement in flexibility after administering the Wells bench test in a stretching, walking and dancing program for 12 weeks. Alves et al. (29) conducted a study with women over 60 years who received two weekly aerobic classes for three months, and found improvement in strength and endurance of lower and upper limbs, physical mobility (speed, agility and balance), flexibility and aerobic endurance. With regard to muscle strength, it is important to take into account some age-related physiological factors. Most studies on neuromuscular function in the elderly focus on the behavior of muscular strength, which is defined as the maximum force a muscle or muscle group can generate at a specific velocity, and of muscle quality, also known as specific tension or strength (30). Under normal conditions the human muscle strength reaches its peak between the ages of 20-30 years, with a slow decrease in the following 20 years. After the age of 65-70 years, the muscle strength begins to decline, and consequently, motor impairment becomes more prevalence in individuals in this age group (31). In the present study, the patient was part of this age group in pre-PRCP with great loss of muscle strength. After a 5-month period, there was a considerable increase in muscle strength.

Harries and Bassey (32) reported that a 15\% decline in muscle strength occurs between the sixth and seventh decades of life, and that there is a 30\% decline of the maximum individual strength every decade of life thereafter. However, our study showed that this decline can be slowed, reversed and stabilized satisfactorily to maintain peripheral muscle strength. In a 12-year longitudinal study with sedentary old men, Frontera et al. (33) observed a decline of $30 \%$ of the isokinetic strength capability. This outcome allows us to observe the negative effects of a sedentary lifestyle on all muscles. Okuma (34) pointed out that for elderly persons to accomplish their tasks, such as climbing stairs, carrying their purchases and kneeling, they need not only a little cardiovascular fitness, but also other fitness conditions, such as muscular strength, and muscular endurance. These findings reinforce the importance of RT and enable us to say that its administration has 
also produced significant functional improvements in the patient's quality of life.

\section{Conclusion}

In this study, the 5-month CPRP, held twice weekly, provided a better exercise tolerance with the improvement of the respiratory hemodynamic parameters of the patient with functional limitations and diagnosed with acute myocardial infarction and bronchial asthma. In addition, the CPRP proved to be effective in increasing exercise capacity, upper limb strength and flexibility of the posterior chain and lower limbs. The increase in exercise capacity assessed by the DW in the 6MWT was also a better prognosis and with a lower risk of death. However, the inherent limitations of this case report should be considered.

\section{References}

1. Santos-Filho RD, Martinez TLR. Fatores de risco para doença cardiovascular: velhos e novos fatores de risco, velhos problemas! Arq Bras Endocrinol Metab. 2002;46(3):212-4.

2. Toscano CM. As campanhas nacionais para detecção das doenças crônicas não transmissíveis: diabetes e hipertensão arterial. Cienc Saude Colet. 2004;9(4):885-95.

3. Maciel ACC, Guerra RO. Limitação funcional e sobrevida de idosos de comunidade. Rev Assoc Med Bras. 2008;54(4):347-52.

4. Rosa TEC, Bemicio MHD, Latorre MRDO, Ramos LR. Fatores determinantes da capacidade funcional entre idosos. Rev Saude Publica. 2003;37(1):40-8.

5. Ribeiro A, Younes C, Mayer D, Fréz AR, Riedi C. Teste de caminhada de seis minutos para avaliação de mulheres com fatores de risco cardiovascular. Fisioter Mov. 2011;24(4):713-9.

6. ATS Committee on Proficiency Standards for Clinical Pulmonary Function Laboratories. ATS statement: guidelines for the six-minute walk test. Am J Respir Crit Care Med. 2002;166(1):111-7.

7. Rodrigues CEC, Dantas EHM. Força e flexibilidade: efeitos do treinamento de força sobre a flexibilidade. Fit Perf J. 2002;1(2):29-41.
8. Matsudo SMM. Envelhecimento \& atividade física. Londrina (Brazil): Midiograf; 2001. Portuguese.

9. Grimley-Evans J. Fallers, non-fallers and Poisson. Age Ageing. 1990;19(4):268-9.

10. Gass M, Dawson-Hughes B. Preventing osteoporosis-related fractures: an overview. Am J Med. 2006;119(4):3-11.

11. Borba-Pinheiro CJ, Carvalho AMCG, Silva NSA, Bezerra JCP, Drigo AJ, Dantas EHM. Efeitos do treinamento resistido sobre variáveis relacionadas com baixa densidade óssea de mulheres menopausadas tratadas com alendronato. Rev Bras Med Esporte. 2010;16(2):121-5.

12. Figliolino JAM, Morais TB, Berbel AM, Corsol SD. Análise da influência do exercício físico em idosos com relação a equilíbrio, marcha e atividade de vida diária. Rev Bras Geriatr Gerontol. 2009;12(2):227-38.

13. ATS Committee on Proficiency Standards for Clinical Pulmonary Function Laboratories. ATS Statement: guidelines for the six-minute walk test. Am J Respir Crit Care Med. 2002;166(1):111-7.

14. Pollock ML, Wilmore JH, Fox SM. Exercícios na saúde e na doença. Rio de Janeiro: Medsi; 1986.

15. Figueiredo IM, Sampaio RF, Mancini MC, Silva FCM, Souza MAP. Teste de força de preensão utilizando o dinamômetro Jamar. Acta Fisiatr. 2007;14(2):104-10.

16. Soares AV, Suzuki S, Metzler CT. Testes preditivos para a recuperação motora do membro superior em pacientes hemiparéticos pós-AVC. Rev Cientifica JOPEF. 2008;8(1):36-42.

17. Bittner V, Weiner DH, Yusuf S, Rogers WJ, McIntyre KM, Bangdiwala SI, et al. Prediction of mortality and morbidity with a 6-minute walk test in patients with left ventricular dysfunction. SOLVD Investigators. Jama. 1993;270(14):1702-7.

18. Rasekaba T, Lee AL, Naughton MT, Williams TJ, Holland AE. The six-minute walk test: a useful metric for the cardiopulmonary patient. Intern Med J. 2009;39(8):495-501.

19. Cote CG, Casanova C, Marin JM, Lopez MV, Pinto-Plata V, de Oca MM, et al. Validation and comparison of reference equations for the 6-min walk distance test. Eur Respir J. 2008;31(3):571-8. 
20. Opasich C, De Feo S, Pinna GD, Furgi G, Pedretti R, Scrutinio D, et al. Distance walked in the 6-minute test soon after cardiac surgery: toward an efficient use in the individual patient. Chest. 2004;126(6):1796-801.

21. Rubim VSM, Drumond Neto C, Romeo JLM, Montera MW. Valor prognóstico do teste de caminhada de seis minutos na insuficiência cardíaca. Arq Bras Cardiol. 2006;86(2):120-5

22. Barata VF, Gastaldi AC, Mayer AF, Sologuren MJJ. Avaliação das equações de referência para predição da distância percorrida na teste de caminhada de seis minutos em idosos saudáveis brasileiros. Rev Bras Fisioter. 2005;(2):165-71.

23. Kervio G, Carre F, Ville NS. Reability and intensity of the six-minute walk test in healthy elderly subjects. Med Sci Sports Exerc. 2003;35(1):169-74.

24. Enright PL, McBurnie MA, Bittner A, Bittner V, Tracy RP, McNamara R, et al. The six minutes walk test - a quick measure of functional status in elderly adults. Chest. 2003;123(2):387-98.

25. Bautmans I, Lambert M, Mets T. The six-minute walk test in community dwelling elderly: influence of health status. BMC Geriatr. 2004;4:6.

26. Baptista VC, Palhares LC, Oliveira PPM, Silveiro Filho LM, Vilarinho KAS, Severino ESBO, et al. Teste de caminhada de seis minutos como ferramenta para avaliar a qualidade de vida em pacientes submetidos à cirurgia de revascularização miocárdica. Rev Bras Cir Cardiovasc. 2012;27(2):231-9.

27. Shephard RJ. Aging and exercise. In: TD Fahey (Editor). Encyclopedia of Sports Medicine and Science. Wellington (New Zeland): Internet Society for Sport Science; 1998.

28. Hoerger WK, Hopkins DR. A comparison of sit and the modified sit and reach in the measurement of flexibility in woman. Res Q Exer Sport. 1992;63(2):191-5.

29. Alves RV, Mota J, Costa MC, Alves JGB. Aptidão física relacionada à saúde de idosos: influência da hidroginástica. Rev Bras Med Esporte. 2004;10(1):31-7.

30. Fleck SJ, Kraemer WJ. Fundamentos do treinamento de força muscular. Porto Alegre (Brazil): Artmed; 1999.

31. Duthie EH, Katz PR. Practice of Geriatrics. Philadelphia: Saunders Co; 1998.
32. Harries UJ, Bassey EJ. Torque velocity relationship for the knee stensors en women in their 3rd and 7th decades. Eur J Appl Physiol Occup Physiol. 1990;60(3):187-90.

33. Frontera WR, Hughes VA, Fielding RA, Fiatarone MA, Evans WJ, Roubenoff R. Aging of skeletal muscle: 12-yr longitudinal study. J Appl Physiol. 2000;88(4):1321-6.

34. Okuma SS. O idoso e a atividade física: fundamentos e pesquisa. Campinas: Papirus; 2002. Portuguese.

Received in 06/22/2014

Recebido em 22/06/2014

Approved in 05/16/2016

Aprovado em 16/05/2016 